\title{
Finite Element Analysis over Geopolymer Concrete using Abaqus
}

\author{
A.Chithambar Ganesh, M. Muthukannan
}

\begin{abstract}
In the recent decade, lots of efforts are being taken to completely replace cement concrete with the Geopolymer concrete. Complete understanding of the Geopolymer concrete is necessary for the effective replacement of cement concrete. This research work deals with the comparison of flexural behavior of ordinary cement concrete and Geopolymer concrete is carried out. Abaqus CAE tool is effectively used to study the flexural behavior like load deflection curve, deformation pattern and the cracking pattern. Further experimental studies were carried out and the ultimate deflection was recorded and compared with results obtained from the Abaqus results. Fair results have been obtained in this study and it unleashes a lot of scope in Geopolymer concrete.
\end{abstract}

Keybord: This research work deals with the comparison of flexural behavior of ordinary cement concrete

\section{INTRODUCTION}

$\mathrm{N}_{\text {ow-a-days, higher amounts of } \mathrm{CO} 2 \text { emission during }}$ the Cement production leads to the serious environmental issues like greenhouse effect and global warming. Cement production involving large volume of carbon dioxide emission forms theback bone of construction field. [1-3]. Recent demands towards higher and stronger buildings with complicated architectural designs and concrete mixtures of higher quality gives rise to the new developments in concrete with low $\mathrm{co} 2$ emissions which increases its physical, mechanical and chemical properties by introducing additives such as slag, natural pozolanic, sand and limestone. Geo polymer is an inorganic material made from utilization of waste materials such as flyash, GGBS [4-5]. Geopolymer concrete is producedthroughthe activation of alumina-silicates at room temperature or somewhat increased temperature. Geopolymer concrete seeks limelight due to its exceptionalengineering properties, reduced shrinkage, and resistance to fire. ordinary cement concrete [6-8]. In order to completely replace conventional cement concrete, geopolymer concrete should possess better flexural strength. Flexural strength measures the capability of a material to withstand bending. Being an eco-friendly construction material, it replaces Flexural strength is the measure of tensile strength of the beam or slab. A member that is subjected to both compressive and tensile force is termed as flexural member.

Revised Manuscript Received on December 5, 2019

* Correspondence Author

A. Chithambar Ganesh, Assistant Professor, Department of Civil Engineering,Kalasalingam University,chithambarmailid@gmail.com

Dr. M. Muthukannan, Professor, Department of Civil Engineering,Kalasalingam University,civilkannan@gmail.com
To predict the behavior of a material, it is essential to have a complete understanding about the flexural behavior of building material. This property can be assessed using three point or centre point loading method as stated by ASTM C78 or ASTM C293. In the progress of this test it is difficult to find the crack propagation and load distribution.

Abaqus is a Finite Element Analysis (FEA) tool that aids computer drawing and helps to analyze the mechanical components and visualize FEA results. Abaqus CAE has been reported as the accurate tool for conducting Finite element analysis. Owing to the increased versatility in modeling capabilities and ability to incorporate new materials this tool is famous with engineering research institutes. Abaqus comprises of modeling features, processing options and post processing animation display options which allows the users to simulate the behavior of their profound product and predict its functions. This feature can be advantageously utilized for understanding load deflection behavior, cracking pattern, stress strain curve [913]. In this research work, an investigation has been conducted on the flexural behavior of Geopolymer concrete and the ordinary conventional cement concrete on various parameters such as load deflection behavior and cracking pattern. Specimens were casted and flexural tests were conducted and the results are validated in Abaqus CAE.

\section{METHODOLOGY}

In this research work, flexural behavior of the geopolymer concrete and conventional concrete are compared for their load deflection behavior, stress strain curve, cracking pattern.Further specimensof prismatic size 500 X 100 X 100 $\mathrm{mm}$ were casted and tested for their deflection. These experimental results are used to validate the deflection results derived from the tool.

\subsection{Experimental work}

Cement concrete synthesized in this research work is of M30 grade and the materials are proportioned as per IS 10262-2000.Cement concrete is made of cement of grade 33 with specific gravity 3.15 . Fine aggregate is $\mathrm{M}$-sand with specific gravity of 2.3. It is classified in to zone 3. Bulk density of M-sand is found to be $1702 \mathrm{~kg} / \mathrm{m}^{3}$. Fineness modulus of M-sand is 2.36. Coarse aggregate of size $20 \mathrm{~mm}$ is utilized and its specific gravity is found to be 2.9. The bulk density of the material is $1456 \mathrm{~kg} / \mathrm{m}^{3}$. Geopolymer concrete is produced based on the B.V Rangans mix design. GPC is Ground Granulated Blast Furnace Slag (GGBS) based. GGBS has specific gravity of 2.9.

Published By: 


\section{Finite Element Analysis over Geopolymer Concrete using Abaqus}

Combination of sodium silicate and sodium hydroxide solution is used as the alkaline solution and is to be prepared one day prior to casting. Sodium hydroxide pellets are made in to solution of 13 Molarity. Ambient curing is done for the Geopolymer concrete.

Both the concretes are casted in to specimens of prismatic shape of size 500 X 100 X $100 \mathrm{~mm}$. After 28 days of curing, they are taken out and tested in the flexural testing machine. Strain gauges are fitted at the soffit of the beam and the deflections of the beam at the ultimate loads are noted down to check the accuracy of Abaqus.

\subsection{Analytical work}

A 3D finite element model was developed to simulate the performance and various failures modes of plain concrete in comparison with geopolymer concreteby using Abaqus software.In this modeling, a continuum stress/displacement three dimensionalelement eight node brick reduced integration (C3D8R)element of plain concrete beam having dimensions of $500 \times 100 \times 100 \mathrm{~mm}$ is modeled. Figure 1 shows the modeling of concrete specimen. Geopolymer concrete and cement concrete specimens are modeled in the Abaqus CAE. Concrete is a heterogeneous, non-linear and orthotropic material. All concrete structure will crack to some extent, due to shrinkage and tension. So, the elastic parameters required to establish the relation are density, elastic modulus and poisson's ratio. The input properties are feed in to Abaqus CAE as tabulated in Table1.

Table 1. Input data for Abaqus

\begin{tabular}{|c|c|c|c|c|}
\hline Material & Grade & $\begin{array}{c}\text { Poison } \\
\text { Ratio }\end{array}$ & $\begin{array}{c}\text { Elastic } \\
\text { Modulus } \\
\text { (N/mm2) }\end{array}$ & $\begin{array}{c}\text { Uniaxial } \\
\text { compressive } \\
\text { strength } \\
\text { (N/mm2) }\end{array}$ \\
\hline $\begin{array}{c}\text { Cement } \\
\text { concrete }\end{array}$ & M30 & 0.18 & 27386 & 33 \\
\hline $\begin{array}{c}\text { Geopolymer } \\
\text { concrete }\end{array}$ & G30 & 0.20 & 385000 & 43 \\
\hline
\end{tabular}

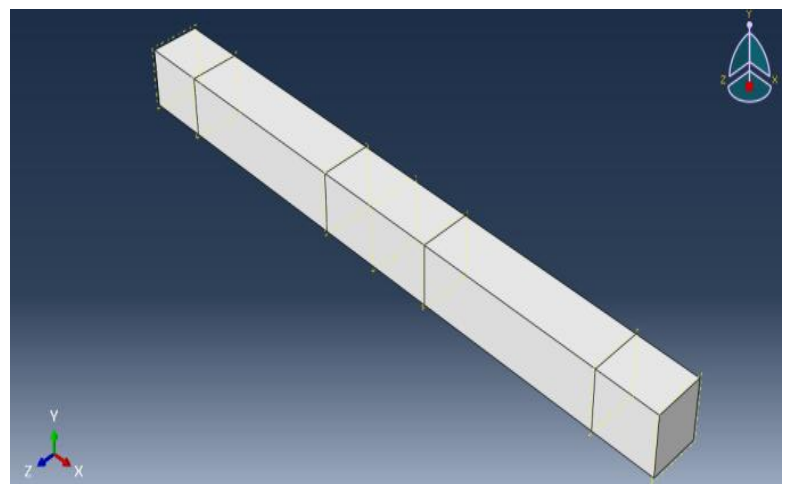

Figure 1.Modelingof concrete beam

After assigning the material properties, an input file is created which is then imported to create a mesh.Meshing is the process of generating nodes and elements. A mesh is generated by defining nodes and connecting them to define the elements. Accuracy increases with the number of elements but these increases the processing time.Figure 2 show the meshed models with solid C3D8R Beam element. Boundary conditions are specified as per to suit the two point loading conditions at $50 \mathrm{~mm}$ from the end of the beam.
Loading conditions are made at $63.5 \mathrm{~mm}$ from the centre on both the sides. This is clearly depicted in Figure 3. Request for field output and historical output is made to run the job analysis.

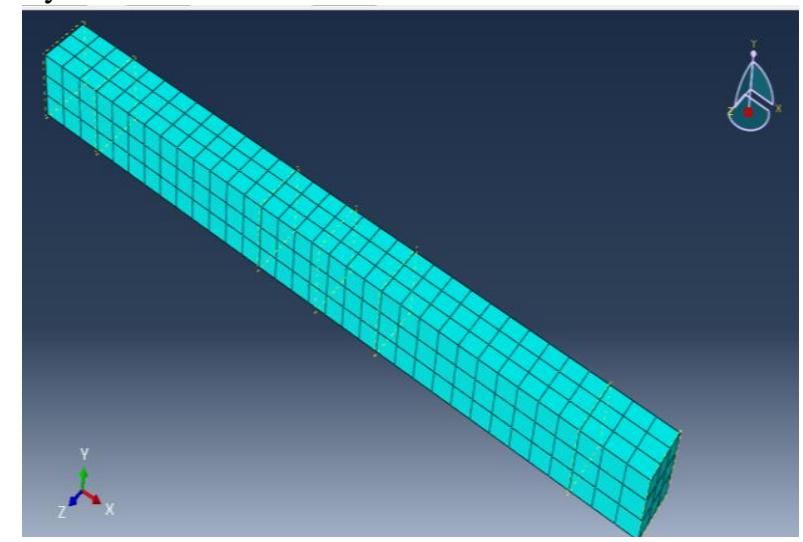

Figure 2.Meshed concrete beam

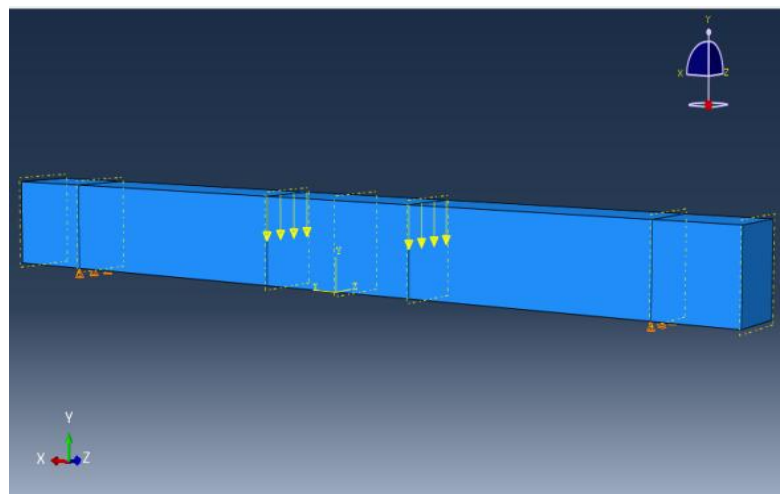

Figure 3Boundary and loading conditions of plain concrete beam

\section{RESULTS AND DISCUSSION}

\subsection{LOAD AND DEFLECTION}

Maximum stress patterns yielded by the ordinary cement concrete and geopolymer concrete is as shown in the figure 4 and Figure 5 . Figure 4 clearly depicts that maximum stress occurs at all parts of the beam and are liable to get deformed easily .from figure 5 it is clear that, geopolymer concrete exhibits maximum stress only at the soffit of the beam.

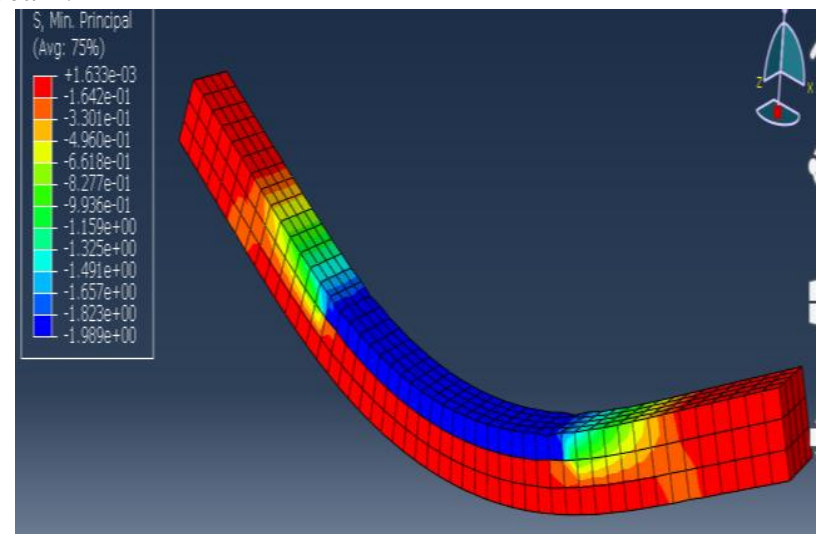

Figure 4 Stress distribution of plain cement concrete

Published By

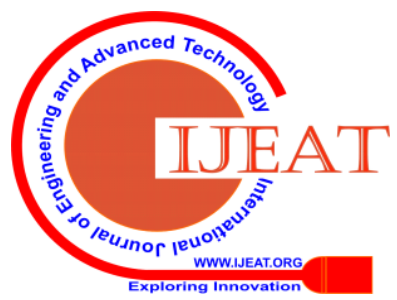




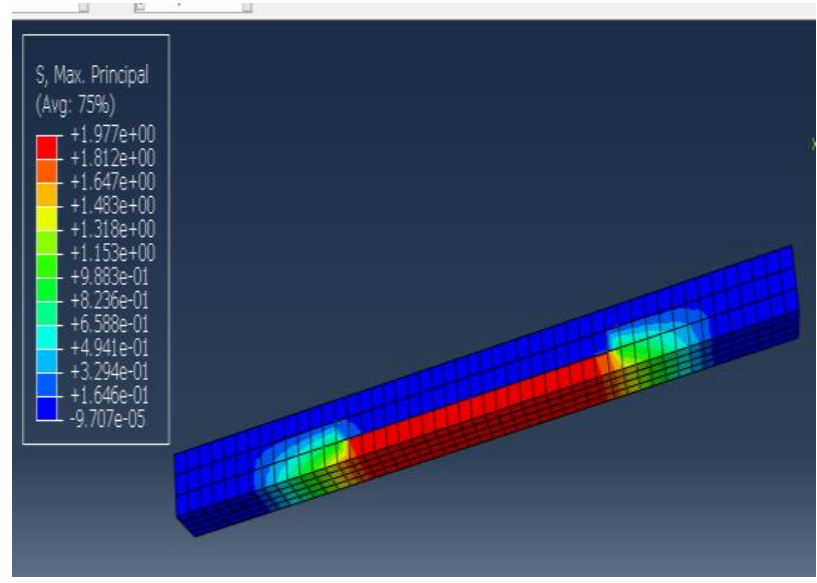

Figure 5 Stress distribution of geopolymer concrete

From the analysis, it is load and deflection behavior of the plain cement concrete and geopolymer concrete can be well understood from the Figure 6 and Figure 7 . From Figure 6 and Figure 7, it is clear that geopolymer concrete yields a lesser strain value compared to the ordinary cement concrete. This is due to the brittle nature of the geopolymer concrete .however geopolymer concrete bears a greater load carrying capacity than the ordinary cement concrete.

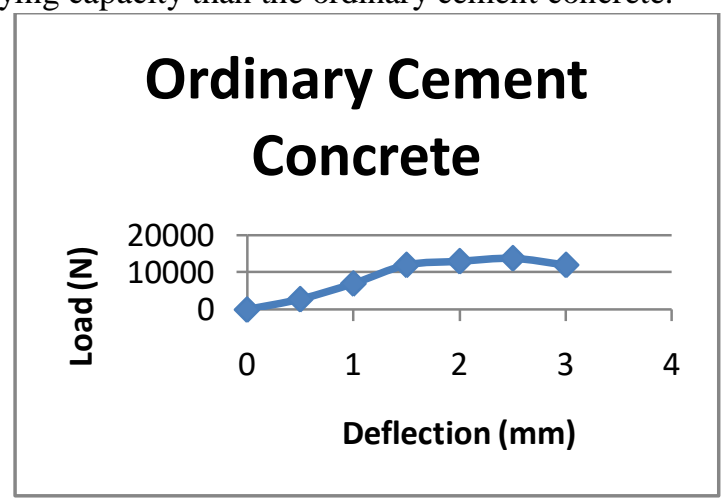

Figure 6 Load- Deflection behavior of ordinary cement concrete

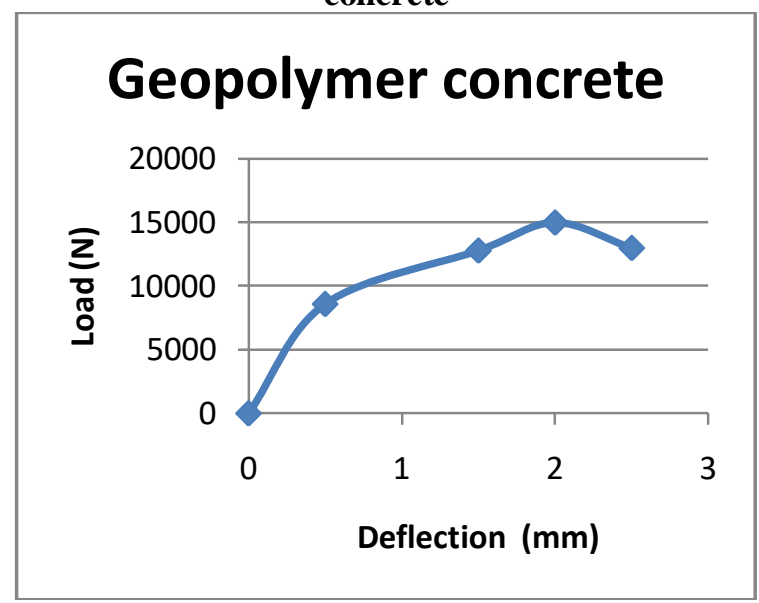

Figure 7 Load- Deflection behavior of geopolymer concrete

The above values obtained from Abaqus CAE tool was validated with experimentally obtained values that are tabulated in table 2.Table 2 shows the percentage of deviation of the obtained results.
Table 2. Comparison of Values

\begin{tabular}{|c|c|c|c|c|}
\hline & \multicolumn{2}{|c|}{$\begin{array}{l}\text { Ordinary cement } \\
\text { concrete }\end{array}$} & \multicolumn{2}{|c|}{$\begin{array}{l}\text { Geopolymer } \\
\text { concrete }\end{array}$} \\
\hline & $\begin{array}{c}\text { Strengt } \\
\mathbf{h} \\
\left(\mathrm{N} / \mathbf{m m}^{2}\right. \\
)\end{array}$ & $\begin{array}{c}\text { Deflectio } \\
\text { n (mm) }\end{array}$ & $\begin{array}{c}\text { Strengt } \\
\text { h } \\
\left(\mathrm{N} / \mathbf{m m}^{2}\right. \\
)\end{array}$ & $\begin{array}{c}\text { Deflectio } \\
\text { n (mm) }\end{array}$ \\
\hline $\begin{array}{c}\text { Experiment } \\
\text { al }\end{array}$ & 6.3 & 3.5 & 7.4 & 3 \\
\hline Analytical & 5.52 & 3.12 & 6 & 2.6 \\
\hline $\begin{array}{l}\text { Percentage } \\
\text { of deviation }\end{array}$ & $14 \%$ & $12 \%$ & $23 \%$ & $15 \%$ \\
\hline
\end{tabular}

From Table 2,it is evident that the values obtained from the analytical tool are found to be in accordance with the experimentally obtained results.

\subsection{CRACKING PATTERN}

Cracking pattern exhibited by ordinary cement concrete and geopolymer concrete is shown in the figure 8 and figure 9.cracking pattern is found to be similar for both the concrete specimens. but the intensity of crack is found to be more on the ordinary cement concrete than the geopolymer concrete.

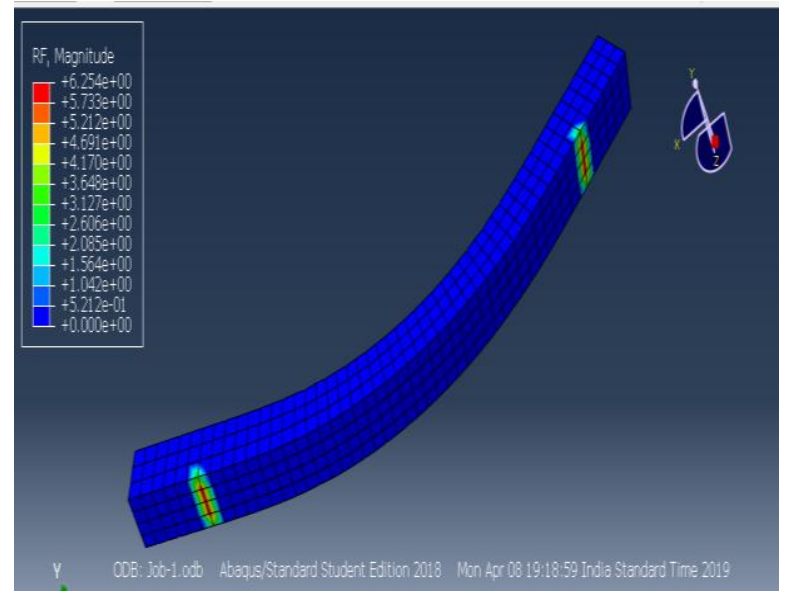

Figure 8. Cracking pattern of ordinary cement concrete

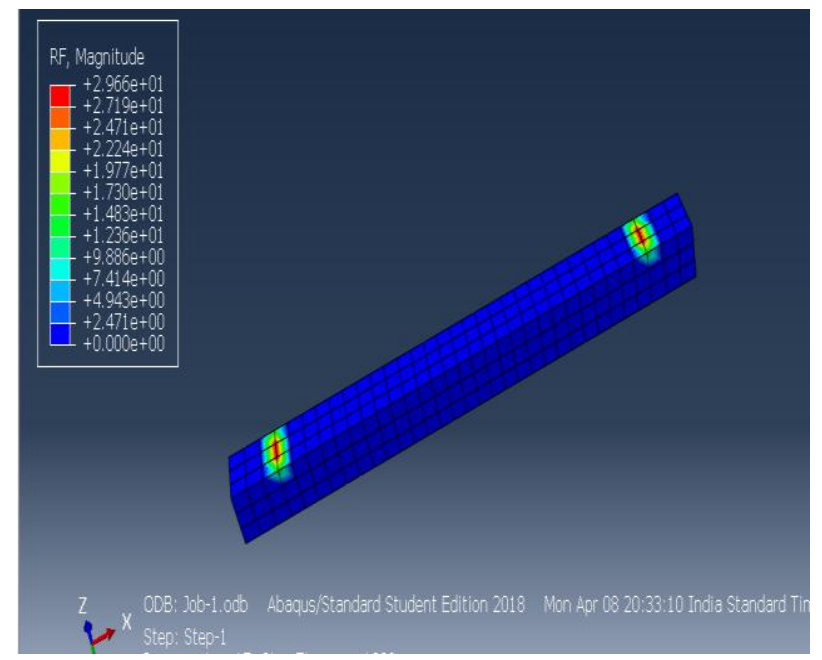

Figure 9. Cracking pattern of geopolymer concrete

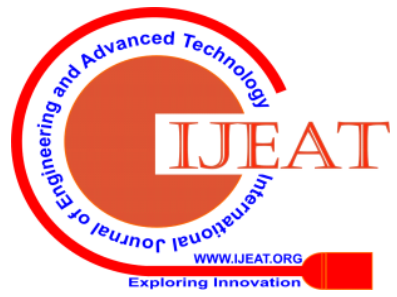




\subsection{DEFORMATION PATTERN}

Deformation pattern of the geopolymer concrete and ordinary cement concrete is as shown in the Figure 10 and Figure 11.From the figures it is clear that both the specimens deform in a similar way with more deflection at the centre of the soffit of the beam. Geopolymer concrete shows less deflection than the ordinary cement concrete

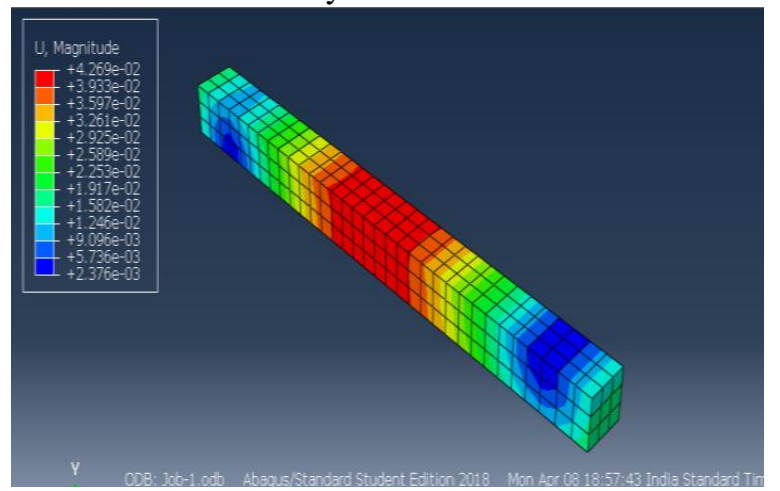

Figure 10. Deformation pattern of Geopolymer concrete

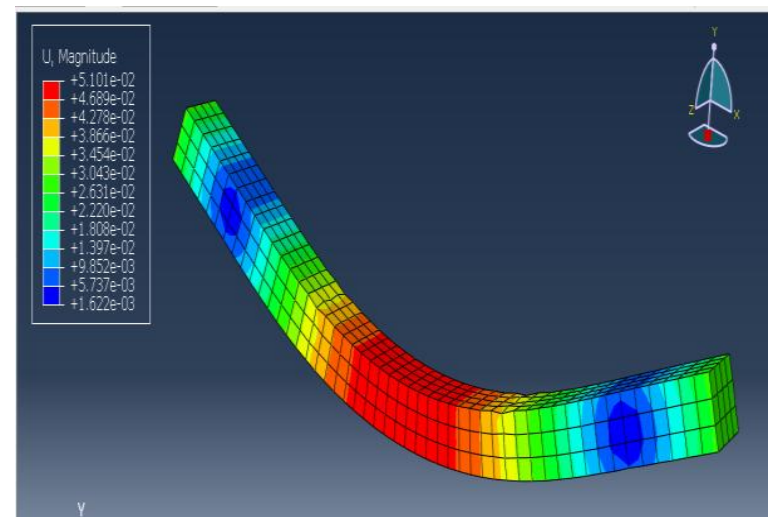

Figure 11.Deformation pattern of Ordinary Cement Concrete

\section{CONCLUSION}

- The analytically determined values were found to be in relation with the experimentally obtained values. the deformation pattern of the both concrete specimens were found to be same

- Geopolymer concrete exhibits lesser deflection than the ordinary cement concrete

- Cracking patterns are similar for both the concrete specimens

- Geopolymer concrete undergoes lesser strain with higher load carrying capacity than the ordinary cement concrete

- Stress distribution is found to be even for the geopolymer concrete

- This study unveils lot of potential in the environs of geopolymer concrete

\section{REFERENCE:}

1. Kumaravel.S, Thirugnanasambandam.S, Antony Jeyasehar.C, Flexural Behavior of Geopolymer Concrete Beams With GGBS, The IUP Journal of Structural Engineering, (7) (1) (2014)

2. Abdul Aleem.M.I, Arumairaj.P.D,Geopolymer Concrete- A Review, International Journal of Engineering Science and Energy Technologies, (1) (2) (2012) 118-122
3. Luigi, Caleb Benjamin, Experimental Study of Properties Of Geopolymer Concrete With Polypropylene Fibres, Journal of Advanced Research in Dynamical and Control System, (8) (9) (2016)

4. Padmanaban.M.S, Sreerambabu.J, Geopolymer Concrete with GGBS (Ground Granulated Blast Furnace Slag), International Journal of Engineering Science and Research Technology, (7) (2) (2018) 629-636

5. Anusha, Dheekshith.K, Study of Geopolymer Concrete Using GGBS, International Research Journal of Engineering and Technology, (4) (2) (2017) 1550-1556

6. Keerthy.V, HimathKumar.Y, Experimental Studies on Properties of Geopolymer Concrete with GGBS and Fly ash, International Journal of Civil Engineering and Technology, (8) (1) (2017) 602-609

7. Kamal Neupane, Des Chalmers, Paul Kidd, High Strength Geopolymer Concrete Properties, Advantages and Challenges, Advance in Materials (7) (2) (2018) 15-25

8. Prakul Thakur, Khushpreet Singh, A Review on Geopolymer Concrete: A Green Concrete, International Research Journal of Engineering and Technology, (5) (5) (2018) 1765-1769

9. Ram Panth, Syed AnwarulHaque, Syed AshfaqHussain, Ziyad Ahmed Hussain, Syed TafazulHussain, Geopolymer Concrete: A Review in Indian Context, International Journal of Current Engineering and Scientific Research, (5) (3) (2018) 75-78

10. Amir Mohammad Amiri, Amin Olfati, ShimaNajjar, PeymanBeiran Vane, NaseriFart.M.H, The Effect of Fly ash on Fluxural Capacity Concrete Beams, Advance in Science and Technology Research Journal, (10) (30) (2016) 89-95

11. Ali Raza, QaiseruzZaman Khan, Afaq Ahmad, Numerical Investigation of Load-Carrying Capacity of GFRP Reinforced Rectangular Concrete Member Using CDP Model in ABAQUS, Advances in Civil Engineering, (Article id 1745341) (2019)

12. Tejaswini.T, Rama Raju.M, Analysis of RCC Beam Using ABAQUS, International Journal of Innovation in Engineering and Technology, (5) (3) (2015) 248-255

13. Sethuraman.V.S, Suguna.K, Raghunath.P.N, Numerical Analysis of High Strength Concrete Beams using ABAQUS, International Jouranl of Applied Environmental Sciences, (12) (1) (2017) 201-210

\section{AUTHORS PROFILE}

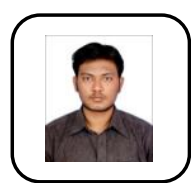

Mr. A. Chithambar Ganesh, completed his M.Tech in Structural Engineering in VIT University, Vellore in the year 2015. He completed his Bachelor of Engineering under Anna University in the year 2012. He is working as Assistant Professor in Department of Civil Engineering at Kalasalingam University, Tamilnadu, India. His main thrust research areas are Geopolymer concrete and Fiber reinforced concrete.

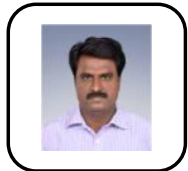

Dr.Muthukannan M completed his Ph.D in Civil Engineering in Anna University, Chennai in the year 2010. He completed Master of Engineering in the field of Transportation Engineering and Management in College of Engineering, Guindy, Chennai in the year 2004. He completed his Bachelor of Engineering under Madurai Kamarajar University in the year 2000. He is presently working as a Professor in Civil Engineering department at Kalasalingam University, Tamilnadu, India. He is guiding for many Ph.D scholars in the field of transporation engineering and computer applications in transportation network using graph theory. He has published various quality papers in the reputed journals. His main thrust research areas are transportation network design, transport management and travel demand management.

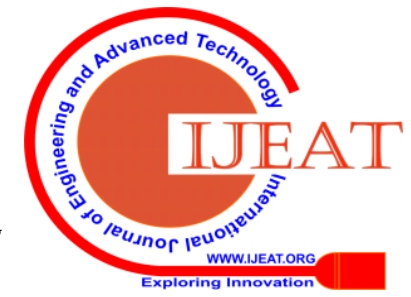

